\title{
HUMAN RESOURCES POLICY IN POLICE ORGANIZATION AS A NEW SECURITY CHALLENGE - STUDY OF CANTON TUZLA/ BOSNIA AND HERZEGOVINA
}

\author{
Jasmin Ahić, PhD \\ Faculty of Criminalistics, Criminology and Security Studies, \\ University of Sarajevo \\ E-mail: jahic@fkn.unsa.ba \\ Admir Hadžikadunić, PHD \\ Faculty of Criminalistics, Criminology and Security Studies, \\ University of Sarajevo \\ E-mail: ahadzikadunic@fkn.unsa.ba \\ Fadil Šljivić. MA \\ Ministry of Interior, Bosnia and Herzegovina, Tuzla
}

\begin{abstract}
:
Personnel is an essential prerequisite for any organization. Hence proper analysis and review of this issue cannot is of utmost importance for a particular organization. Staff may be a great value and wealth of a company. Personnel cannot be seen exclusively through numbers and statistical data because it represents an important productive force. Especially, police force success is increasingly dependent on the ability, responsibility, and professional morale of the staff. The structure of human resources is extremely important in the study and in the analysis of the phenomena of human resources management (HRM), since it signifies the way in which parts of a whole organization are connected and mutually arranged. The relationships that exist between the parts of a coherent whole form are the basis of the very term "structure". The structure of HR (bosn. kadar) encompasses the composition of experts, their role, and characteristics within a particular organization. Identification of the basic characteristics of the staff that determine the personnel structure, as well as the interrelationships between them, is a very complex task in the study of the personnel structure.
\end{abstract}


The authors present an analysis of the human resources function of the police structure in the Ministry of Internal Affairs of Tuzla Canton of $\mathrm{FBiH}(\mathrm{BiH})$. The article aims to give a scholarly and practical contribution towards further development of personnel planning and establishment of an adequate structure and staff dynamics, i.e. provision of required staff profiles and qualification levels of police officers and employees in the Ministry of the Interior Affairs of Tuzla Canton.

Key words: HRM, police work, basic capabilities, Tuzla Canton BiH, analysis.

\section{INTRODUCTORY NOTES}

The structure of personnel and the analysis of personnel is an extremely important part of the study phenomena. Structure signifies the way in which parts of a whole are connected and mutually arranged. The relationships that exist between the parts of a coherent whole form the basis of the term "structure". The structure of cadres (kadar in Bosnian) represents the composition of employees, their role and characteristics within one observed entity.

Determining the basic characteristics and characteristics of staff that characterize the personnel structure as well as the interrelationships between them is a very complex task in the study of the personnel structure.

There are a large number of factors that affect the human structure, its sustainability and internal cohesion. There is an increasing interest in science to study the issues related to the change of staff structure (Stanković, 2007).

The personnel structure analysis can be quantitative and qualitative. The greatest number of personnel features requires qualitative analysis. The most important study of the personnel structure is based on two principles: micro and macro. Micro human resource research today is carried out in a number of organizations. It deals with experts from staffing departments, and sometimes by some theorists with a practical purpose. These are studies at the level of empirical studies. Macro expert staff structure is tied to the country as a whole. Macroplanning provides the ability to look at staff (structures) through a wider and more complete picture of staff development.

Job analysis is defined as the process of collecting, studying and evaluating all relevant job-related data: the nature and content of the work, the working conditions, the requirements regarding the position of executors and the psychophysical characteristics that the job requires of them. There are more job demands in each business. There are and are distinct four sets of demands: knowledge and ability, responsibility, strain 
and working conditions (Appleby, Hunt and Jacob, 1994). The job analysis includes two groups of information. The first relates to the nature and content of the work, the way it is performed, and the other to the perpetrators, ie the knowledge and abilities needed to perform the job. Job analysis is important for other human resource management activities: recruitment, selection and socialization, advancement, training and employee development, performance assessment and security gains, employee protection, employment relationships, etc. Job Analysis provides the necessary information for:

- Human Resource Planning

- Attracting candidates

- Selections and Socialization of Candidates

- Training of employees

- Development of employees

The recruitment process is closely related to job analysis processes, human resource planning and selection as well as rewarding and motivating activities of employees. Recruitment is a complex process whose basic task is to provide a sufficient number of qualified candidates, from which the most suitable to the organization will be chosen. Attracting qualified workforce needs to fulfill vacancies. Human resource needs can be met in two ways: employment of new people and the development of potential already employed. Meeting the needs for human resources depends on several factors:

- Change of organizational structure

- Changes in structure of employees

- Technical - technological advancement of the organization

- Fluctuations of employees

- Organization management estimates and the like.

Internal recruitment is the finding of qualified candidates in the organization itself, and is external to finding potential candidates outside the organization. The best solution is to combine internal and external recourse sources to maximize the benefits and minimize the disadvantages of both recruiting. After the candidate has been admitted, evaluation of the recruitment process is required. At this stage, it is necessary to: analyze the costs, the number of applications, the source having the greatest effect, and the success rate of the recruitment process, and the data obtained will improve the next recruitment process. 


\subsection{Human Resource Management}

Human Resources Management or HRM, as a term and work on new scientific discipline, has appeared in the United States. The first name of this new discipline was "Personal Management". By the end of the seventies the term "Human Resource Management" appeared. The development of this scientific discipline has been strongly influenced by scientific management with emphasis on the study of movement and time, as well as the more pronounced social aspect of the organization. There was also a Behavioral Science with emphasis on individual attitudes, needs and motivations.

Human resources are a constrained active population, and in the broader sense this term encompasses the entire population. In the beginnings of capitalism, instead of human resources, the term Labor Force was used, in France, they are staffs, and in America the term personal is used. Human resources management appears as a management function, and then as part of the organization's science, to be later excelled in a special scientific discipline. This organizational science deals with human resources with a special emphasis on managing these resources.

\subsection{Significance of human resources}

Personnel and human resources are synonyms, so they will be used in further exposition in conjunction with these two concepts. Personnel are an essential prerequisite for any organization and that without analysis and testing this issue cannot be conceived or implemented by a particular organization. Staff is the great value and wealth possessed by the company. Personnel cannot be seen only through numbers and statistical data. Personnel represent an important productive force. Business success is increasingly dependent on the ability, responsibility, and business morale of the staff.

Human resources influence the changing of production relationships, working conditions and mutual economic relations. Personnel and staffing have been studied from various aspects to find out that the work organization and the efficiency of work depend on staff. Personnel function should contribute to the development of personnel planning and the establishment of adequate structure and staff dynamics, i.e. provision of required staff profiles and level of qualifications.

\subsection{Job Analysis}

Job analysis is defined as the process of collecting, studying and evaluating all relevant job-related data: the nature and content of the work, the working conditions, the requirements regarding the position of executors and the psychophysical characteristics 


\section{Seccurity}

that the job requires of them. There are more job demands in each business. There are and are distinct four sets of demands: knowledge and ability, responsibility, strain and working conditions (Appleby, Hunt and Jacob, 1994). The job analysis includes two groups of information:

1. The first concerns the nature and content of the work, the manner of its performance,

2. The second refers to the perpetrator, the knowledge and abilities needed to perform the job.

One of the most important job analysis results is the standard level of performance or performance of employees on the basis of which basic earnings are determined. Job analysis is important for other human resources management activities:

1. Recruitment,

2. Selections and Socialization,

3. Maintaining progress,

4. Training and development of employees,

5. Estimates of performance and earnings of security and protection of employees,

6. Labor Relations,

Job Analysis provides the necessary information for:

1. Human resource planning, 2. Attracting candidates, 3.Selections and socialization of candidates, 4.Training of employees, 5.Development of employees.

\subsubsection{Recruitment}

The recruitment process is closely related to job analysis processes, human resource planning and selection as well as rewarding and motivating activities of employees. Recruitment is a complex process whose basic task is to provide a sufficient number of qualified candidates, from which the most suitable to the organization will be chosen. Attracting qualified workforce should fulfill vacancies. Human resources "needs" can be met in two ways, namely:

- Employment of new and developing the potential of employees already.

Meeting the needs for human resources depends on several factors:

1. Changes in organizational structure,

2. Changes in the structure of employees,

3. Technical-technological advancements of the organization,

4. Fluctuations of employees,

5. Organizational leadership estimates and the like. 
Internal recruitment is the finding of qualified candidates in the organization itself, and is external to finding potential candidates outside the organization. The best solution is to combine internal and external recourse sources to maximize the benefits and minimize the disadvantages of both recruiting. After the candidate has been admitted, evaluation of the recruitment process is required. At this stage it is necessary to:

1. Analyze costs,

2. Number of applications,

3. The sources that had the greatest effect,

4. The success rate of the recruitment process, and the data obtained will improve the next recruitment process.

\subsubsection{Selection}

According to predefined and standardized methods and techniques, selection is made between multiple qualified candidates in order to get the best candidates to work. The quality of employees is essential for all activities in the human resource management process, and therefore the importance of selection is reflected. Selecting candidates to hire: hire those who have the best qualifications. Selection has two basic goals:

1. Forecasting and maximizing the performance of the candidate and their impact on the organization,

2. Avoiding and minimizing mistakes in deciding on a candidate's choice.

The selection process must be fully aligned with other human resources management activities. In order to choose the right candidate, basic assumptions of successful selection must be mett:

1. Job Requirements (required knowledge, skills and personalities),

2. Determining the difference between candidates,

3. Considering the candidate's development potential.

The basic phases of the selection process are:

1. Analysis of submitted applications and supporting documentation,

2. Preliminary interview,

3. Testing,

4. Diagnostic Interview,

5. Verification of references,

6. Job Offer and Medical Examination.

${ }^{1}$ Evaluation of the selection process takes at least 3 months. Confirmation of a good candidate choice is only good. 


\section{SELECTION OF HUMAN RESOURCES FOR POLICE}

\subsection{Police}

Police forces are state administration bodies responsible for maintaining law and order. Police is a word that comes from a French language and less directly from Greek, as a "politei", which refers to government or administration. The word "police" originated in France in the 18th century. The police may also refer to the guard service. The reason for this is the guards who were an early form of police officers.

In most western legal systems, the main role of the police is to discourage and investigate crime, with particular emphasis on crime against persons or property. The police have the ability to drop the freedoms, keep them in detention, and to notify the appropriate authorities.

Police are regularly used as services in various sudden emergency situations, emergency situations, emergency situations, emergency response interventions, emergency services, alarms, medical and fire services, emergency call services. The police may be responsible for reporting minor offenses, e.g. traffic offense violations.

\subsubsection{Structural Analysis of Individual Police Officers' Operations}

Police officers handle situations such as harboring situations, the heaviest forms of public order disturbance, the arrest of armed individuals and groups, the provision of persons in special conditions, the fight against organized crime and terrorism, the fight against the external and internal enemy, the rescue of people affected by natural disasters.

Based on the tasks performed by police officers, a plan and program of their specialization is formed.

Structural analysis serves to identify typical structures, substructures and structural units of some activity. Structural analysis can give an answer to the question of characteristics of typical phases and sub-stages of business (Milanović, 1997). Structural analysis of the work of police officers in special conditions can be put into complex polystructural activities. Activities can have a large part of monostructural cyclic and acyclic activities. The work of police officers is team work. Everyone in this team has a specific task that leads to reaching the goal. Cooperation within this team is indispensable. Teamwork and teamwork are achieved through tactical training. 


\section{PSYCHO - PHYSICAL SELECTION}

\subsection{Psychological assessment in the selection of police officers}

Psychological assessment, in the broader sense, is the process of obtaining information about a particular person from a variety of sources and integrating this information into meaningful interpretation. Clinical evaluation refers to fossil in the psychotherapeutic process. The term "psychological assessment" is different from the term "psychological testing" because testing is a more specific process in which one type of measuring instrument is used - psychological tests (Domino and Domino, 2006; Wright, 2011).

Characteristics of psychological assessment for police needs, through four interrelated questions: when, why, what and how? There is a police officer's assessment before hiring and assessing a police officer who has a working relationship. The second relates to work ability, which can eventually become endangered. The basic purpose of assessing work ability is to determine whether an employee can safely and effectively perform the most important duties within his / her own work (International Association of Chiefs of Police, 2009).

Psychological assessment for police needs has already emerged in the 19th century, indicating a relatively long history of practice. From that time to the present, psychological assessment has become more sophisticated, thanks to progress in the field of psychometrics, psychology, and changes in the demands for police work. The most important change is the development of a community policing paradigm, which made the police job more demanding and more complex (Frank, Henson, Reyns and Klahm, 2008). The work of the community police, apart from keeping the law, needs to focus on counseling, support, and leadership in new initiatives. Thus, they set out the principles of police work (Kastrelar and Gaines, 2011). Inappropriate and unprofessional police behavior can lead to poor publicity, as well as losing citizens' trust in the police. To restore the trust of citizens, sometimes they need years (Lee, 2007). The individual goals of the evaluation in the selection can be divided into two broad categories:

1. Excluding or identifying individuals mentally unstable,

2. Inclusion, i.e. finding individuals who have desirable traits

for a police officer (Toldson, 2006).

The exclusion model has been a dominant model for the selection of candidates for police work (Comeau and Klofas, 2010) for almost two centuries, and today serves as the basis for the selection of future policemen. Psychological assessment, with police officers, can be done after the event that has led to a very stressful situation: fellow 
murder, shooting, testimony to crimes against children, brutal murder (Amendola, 2007). Stress is the most important factor that can lead to reduced work ability. According to Anshel (Anshel, 2000), continued stress weakens the power of judgment, leads to anxiety and depression, and a lack of self-confidence and self-control in life.

Psychological assessment before employment is a specialized examination of the psychological fitness of a candidate. Psychological fitness implies the absence of mental and emotional states that may adversely affect work and effectiveness. Exclusion model, or negative selection, is not an ideal model of human resource selection and police potentials. One of the reasons is precisely that it is not only important to identify cops who might behave problematic behavior, but to identify those who are most qualified to perform their duties. The exclusion model is, however, the most common because there is no unified view of the profile of an ideal policeman, although as desirable characteristics it is mentioned: good personality, incorruptibility, orientation to people, emotional stability, dedication to work, discipline, logical thinking, etc. (Green and Heilburn, 2011).

\subsection{Physical assessment}

In the selection of police officers, the selection of human resources and potentials, using motor tests as a selection tool, is the procedure for selecting certain candidates for a certain police activity, with an assessment of the possibilities of achieving candidate achievements in the exercise of police duties through four equal factors: 1 . The well-being of the final goal Selection of candidates, i.e. model of police activities, 2. Assessment of the renown of motor skills and candidate skills, 3. Assessment of the renown of the process of transformation of the motor skills and 4. Skills of the future candidate and evaluation of the candidate's performance over which the selection was made.

The model of police activities is essential to the applicability of motor tests. Without it, motor tests would be insignificant. In order to successfully complete the selection of personnel for police purposes, a structural analysis of the motions of police officers must be carried out and, on that basis, a model for individual police organizational structures.

The selection of human resources for police needs should be dominated by tests that evaluate motor skills, skills (motor habits), or motor behavior of candidates. Motional testing estimates the very complex human abilities. The results of measuring the manifestation of motor abilities are quantitative data. Motor skills are latent and can therefore be measured. There is a need to have more indicators (motor instruments, tests) on some motor skills (Malacko and Rađo, 2004). 
Motor measurement often refers to motor tests. The division of motor tests is often based on the basic and specific motor of a man. Basic motor implies the presence of those motor skills that each person has, and specific ability is the result of longer dealing with some kinesiology activities.

Upon completion of the general police training, the period of candidate classification in the individual police specialties occurs. This is a case of kinesiology but not isolated, because this is an interdisciplinary procedure, requires inclusion of other scientific disciplines.

\section{OVERVIEW OF THE ORGANIZATION OF THE MINISTRY OF INTERNAL AFFAIRS OF TUZLA CANTON}

\subsection{Basic information on the Ministry of Interior and Police of Tuzla Canton}

The Ministry of the Interior of Tuzla Canton (in text MUP TK), carries out tasks and tasks in the territory of this Canton, as defined in the Constitutions of $\mathrm{BiH}, \mathrm{FBiH}$, Tuzla Canton, and by laws and other regulations and acts of this government institutions. All the regulations issued by the Ministry, as well as all the activities of the Ministry employees, are aligned with the internationally accepted principles of the police service provided for in the Agreement on Reorganization of the Police of the Federation of Bosnia and Herzegovina, signed by the Federation of BiH authorities in Bonn-Petersberg on 25 April $1996^{\text {th }}$. Potentials of the Ministry derive from established partnerships with all segments of the community, which requires the development of an organizational structure that is matched to the changing needs and requirements of citizens and professions.

The Ministry of the Interior of Tuzla Canton seeks to provide an optimal level of public safety and protection in the function of improving the quality of life of the community. The Ministry and the Police Administration continually promote cooperation with the community in all its diversity, based on mutual trust and concern; Enhancing internal and external communication, advocating professional and professional human resource development with the efficient, rational and responsible use of available resources. The basic values that the Ministry consistently follows in its work are: legality, professional impartiality, expertise, accountability, efficiency, economy, publicity and transparency.

The goals set by the Ministry have been achieved through the maximum engagement of available resources to prevent, suppress and detect all forms of crime and other unlawful behavior of individuals and groups, including maintaining a favorable public order and peace in society, continuous improvement of traffic safety and 


\section{Security}

undertaking the legally envisaged measures Actions in other security areas within the scope of the Ministry. These activities represent the priority tasks of the Tuzla Canton Police and are implemented through the permanent preventive work of police services and the application of repressive measures and activities within the framework provided by the Law.

\subsection{Organizational structure of the Ministry of the Interior Affairs of the Canton Tuzla}

The activities of the Ministry of the Interior of Tuzla Canton are carried out within the following basic organizational units:

1. Cabinet of Minister;

2. Sector for administrative and personnel affairs;

3. Sector for material-financial and general affairs;

4. Fire Protection Inspectorate;

5. Police Administration.

\subsection{Police Administration}

Performs administrative, professional and other tasks and tasks in the Canton area, in particular regarding: protection of life and personal safety of people, protection of property, prevention and detection of criminal offenses, detection and capture of perpetrators of criminal offenses and their access to competent authorities in cases when Is not under the jurisdiction of the judicial police, maintaining public order and peace, conducting criminal-technical works, controlling and regulating traffic on the roads, protecting certain persons, controlling traffic of explosive materials, inflammable liquids and gases and providing assistance in order to eliminate the consequences in case of hazards caused by elemental disadvantages And epidemics. The Police Administration consists of:

1. The Police Commissioner's Office, 2. The Uniform Police Department, 3. Criminalistic Police Sector, 4. Sector for Informatics, Telecommunication and Analytics and Police Administrations.

\subsubsection{Police Commissioner's Office}

Immediately helps the police commissar in carrying out the duties outlined in the TK's Internal Affairs Act and the Law on Police Officers of the CC. 


\subsubsection{Division of Uniformed Police of the MUP TK}

It is responsible for monitoring, directing and coordinating the work of police administrations and police stations in the territory of Tuzla Canton in the execution of police affairs, in particular: protection of life, personal and property security of citizens, as well as providing expert assistance to police administrations and police stations while simultaneously exercising control over its work. Officers of this Sector are working on the tasks and tasks of preventing the commission of criminal offenses and the capture of their perpetrators, preventing the disturbance of the public order and peace, the security of traffic affairs as well as other tasks within the competence of the uniformed police. The Sector organizes protection activities against terrorist and violent acts, i.e. armed rebellion, securing certain personalities in accordance with the law and decisions of the Government of the Republic of Croatia, and participates in the provision of significant events, cultural and sporting events as well as a number of other police affairs. Uniformed police work:

1. Department for Coordination, Education and Guidance,

2. Special Police Support Unit and OBL as well as the Operational Center.

\subsubsection{Sector of Criminalistic Police of the MUP TK}

It immediately follows the situation, trends and incidents of crime in the territory of Tuzla Canton and accordingly organizes plans, directs and coordinates the work of the organizational units in order to undertake operational and other measures to prevent, suppress and detect serious criminal offenses, especially serious property delinquents. Sexual crimes, serious crimes of organized crime, heavy crime in the field of narcotic drug abuse, war crimes and serious criminal offenses against the economy, as well as criminal intelligence, criminal investigation work and KDZ screening. One of the basic tasks of this Sector is to prevent any form of violation of human rights and freedoms through preventive and operational work, to ensure full personal and property protection of every citizen and to achieve cooperation and assistance to domestic and international human rights institutions. The Criminal Police Sector is composed of:

1. General Crime Departments,

2. War Crimes Investigation Departments,

3. Divisions for Juvenile Delinquency and Domestic Violence,

4. Department for Combating Organized Crime,

5. Offices for Combating Economic Crime and Corruption,

6. The Department for Combating Abuse of Narcotic / Drugs,

7. Criminal-Intelligence Support Departments, Criminal Offices and Protection 


\section{THE RESEARCH SUBJECT AND PROBLEM}

The subject of this paper is the structure, profile and levels of qualifications of police officers employed in the Police Administration of the Ministry of Interior of the Tuzla Canton. The subject of this paper is an analysis of the staffing function of the police structure of employees in the police administration of the Ministry of Interior of the Tuzla Canton, which should contribute to the development of personnel planning and establishment of adequate structure and staff dynamics in the Tuzla Cantonal Police Administration.

\section{RESEARCH OBJECTIVES}

The objectives of this study were set based on the subject and the problem of work. The main objective of this paper is to analyze the structure of employees in the police administration of the Ministry of Internal Affairs of Tuzla Canton. According to the basic objective of this paper, individual goals have been set:

1. Analysis of the Rules of Procedure in the allocation of jobs in the Police Administration of the Ministry of Internal Affairs of Tuzla Canton,

2. An analysis of the age structure of the employees in the Police Administration of the Ministry of Internal Affairs of Tuzla Canton,

3. Analysis of the gender structure of employees in the Police Directorate of the Ministry of Internal Affairs of Tuzla Canton,

4. Analysis of the employees of the Police Directorate of the Ministry of Internal Affairs of Tuzla Canton according to the act,

5. Analysis of the qualifications of employees in the Police Directorate of the Ministry of Internal Affairs of Tuzla Canton,

6. Analysis of the number of employees in the organizational units of the Police Administration of the Ministry of Interior of the Tuzla Canton.

7. Analysis of the performance of police tasks in relation to available human resources in the field of operation of the Ministry of Internal Affairs of Tuzla Canton.

\section{METHODOLOGY}

For the purposes of this paper, the data from the Tuzla Canton Ministry of Internal Affairs were used. The analysis of the structure of the employees implies an analysis of the number of employees by: analysis of the procedures according to the Ordinance on distribution of workplaces, analysis of age structure, analysis of pole structure, analysis 


\section{Seccurrity}

of employees by the rank of employees, analysis of professional qualifications, analysis of the number of employees in the organizational units in the Police Administration of the Ministry of Internal Affairs of Tuzla Canton.

\section{DATA ANALYSIS}

8.1. Analysis of the structure of employees in the Police Administration of the Ministry of Internal Affairs of Tuzla Canton (by age/under law of systematization)
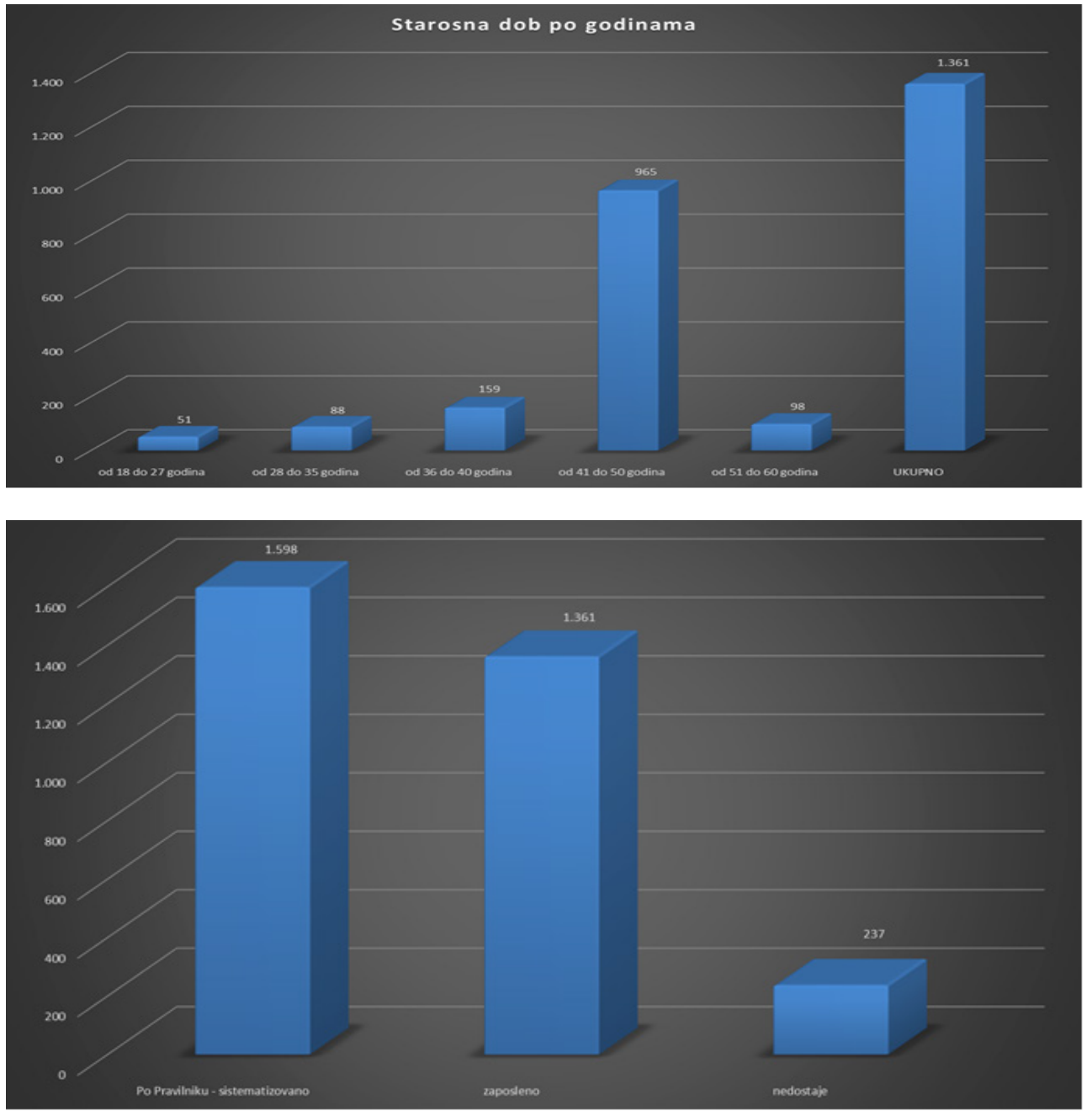


\section{Seccurity}

8.2 Analysis of gender structure of employees in the Police Administration of the Tuzla Canton Ministry of Interior (by rank-čin, by education)
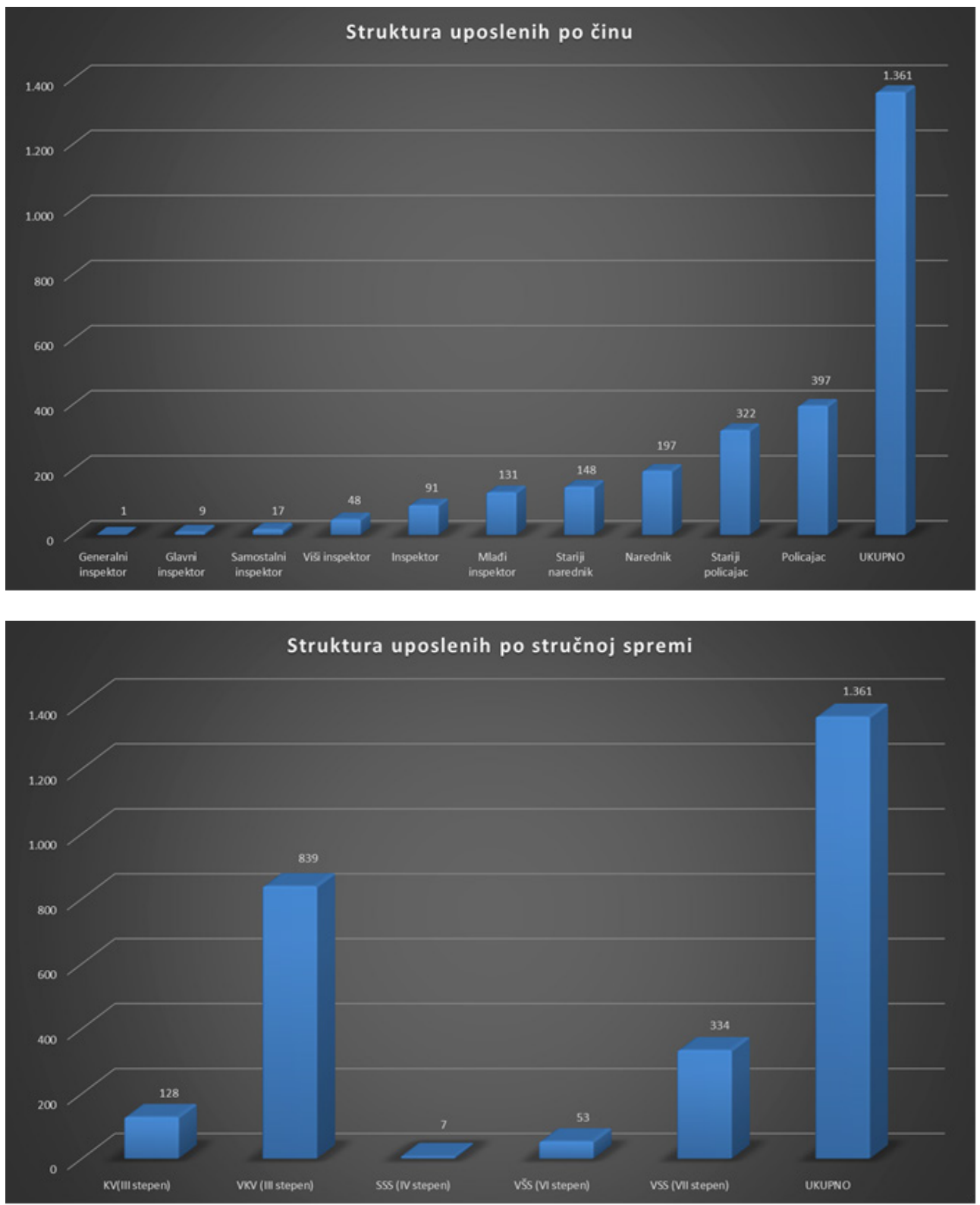


\section{Securirity}

8.3 Analysis of the structure according to the number of employees in the organizational units of the Police Administration of the MUP Tuzla Canton (systematization, educationrank inspector)
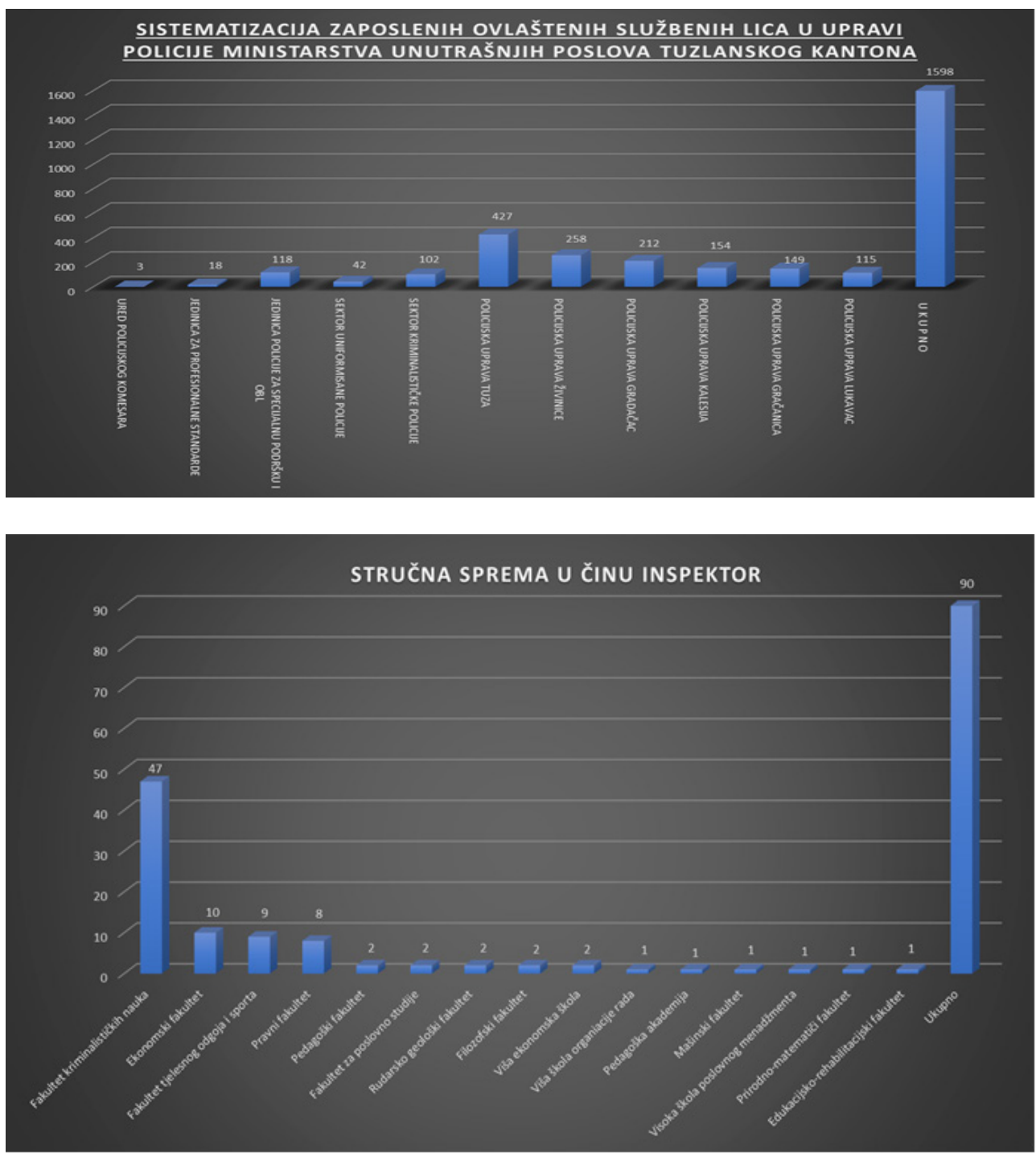


\section{Secururity}

8.4 Analysis of the structure of employees in the police administration of the Tuzla Canton Ministry of the Interior (according to the expert qualification rank "Young Inspector")

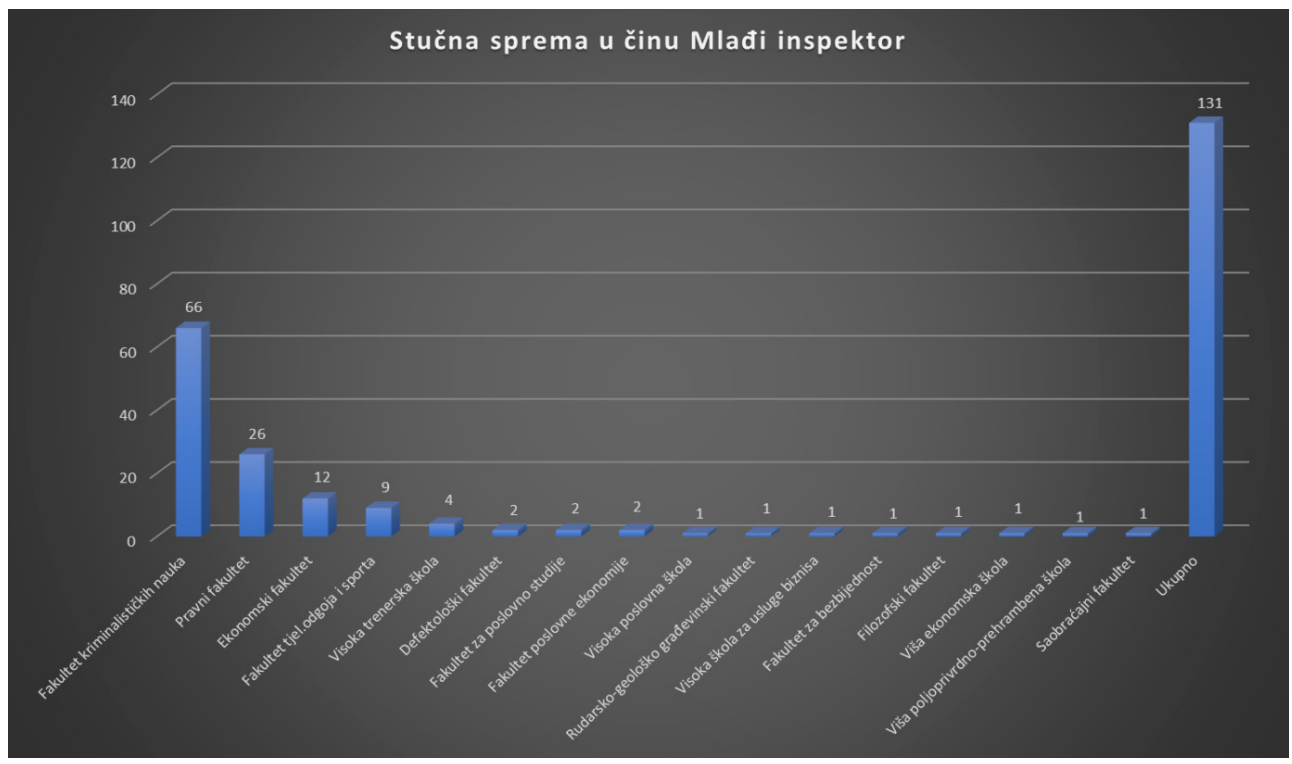

\section{CONCLUDING DISCUSSION}

Analysis of the obtained data related to human resources of the police administration within the Ministry of Internal Affairs of Tuzla Canton (MUP TK) has confirmed the general hypothesis we set at the onset of this research. Namely, the research study entitled "Analysis of Human Resources in the Police Administration of the Ministry of Internal Affairs of Tuzla Canton" has identified the disadvantages of the engaged human resources in performing the jobs and affairs of Mol TK police officers. Nevertheless, despite these shortcomings, the police forces have fulfilled their duties in arelatively effectual manner. The analysis of the efficiency and organization of the police structures of the Ministry of Internal Affairs confirms the thesis that actual crime rate in the area Tuzla Canton in 2016 compared to the previous year displays the following state of affairs: 
1. Reduction of the number of serious criminal offenses

(in total 361 criminal offenses or $6.79 \%$ );

2. Decreased number of reported perpetrators (107 or $2.65 \%)$;

3. The percentage of detected criminal offenses reported by an unknown offender is $40.65 \%$;

4. The percentage of total illumination of crime is $64.31 \%$;

5. 4.492 reports of the perpetration of the criminal offense were filed with the competent prosecutors' offices.

Based on data analysis, we have also come to confirmation of the other hypotheses. The research study "Analysis of Human Resources Resources in the Police Administration of the Ministry of Interior of Tuzla Canton" detect ed a negative trend in terms of the age structure of the police officers employed in the Police Directorate of the Ministry of Internal Affairs of Tuzla Canton. This study also identify a negative trend when it comes to gender balance in the police forces of the MUP TK.

The overal analysis of human resources showes that Ministry did not establish negative trend with regard to the police officers employment in the police of MUP TK in terms of the type of qualification, indicating the non-confirmation placed under the hypothesis of the research. This study found a negative trend of employment of police officers according to the type of qualification.

The human resources analysis at the police administration of the MUP TK could not establish a significant number of police officers with inadequate higher education qualifications compared to the general and special tasks being carried out of their working hours, indicating that the research hypothesis that assumed a significant number of police officers with inadequate education qualifications has not been confirmed. In fact, with this non-affirmation of the auxiliary hypothesis concerning the human resources and their fundamental vocational education (adequate professional qualifications), we point out the necessity of further improvement of the bylaws, i.e. Internal Systematization and the organization of the MUP TK as the most important act governing this very important area for efficient and effective professional functioning of both the MUP, and in particular the MUP Police Administration, as its operative work.

Based on the findings of our research we conclude that the Police Administration of the Ministry of Internal Affairs of Tuzla Canton is on a good way to develop new and more efficient mechanisms and instruments that would improve employees work performances through the mechanisms of recording, resolving and documenting the reported cases as well as through the implementation of the program of training of police officers, civil servants and employees for more efficient job performance. Bearing in mind the identified shortcomings, the system of internal control and auditing has been improved in the function of suppressing corruption in the Ministry of Internal Affairs. 


\section{Security}

\section{REFERENCES:}

1. Amendola, K. L. (2007), "Psychological Fitness for Duty", in: Greene, J. R., The Encyclopedia of Police Science, 3rd ed, New York: Routledge.

2. Appleby J., Hunt, L., Jacob, M. (1994). Telling the Truth about History, New York.

3. Comeau, M. i Klofas, J. (2010). "The Police Recruitment Process", Rochester, NY. (CPSI Working Paper \# 2010-06). Accessed on: http://www.rit.edu/cla/cpsi/ WorkingPapers/2010/2010-06.pdf

4. Davorin-J., Zidar, D. (2012), "Evaulacija primjenjene kineziologije u policiji", Policijska sigurnost, vol. 21, no. 2.

5. Domino, G. and Domino, M. L. (2006), Psychological Testing: An Introduction, Cambridge: Cambridge University Press.

6. Forero C. G., Gallardo - Puyol, D., Maydeu - Olivares, A. and Andres - Pueyo, A. (2009), "A Longitudinal Model for Predicting Performance of Police Officers Using Personality and Behavioral Data", Criminal Justice and Behavior, 36 (6).

7. Frank, J., Henson, B., Reyns, B. i Klahm, C. (2008). "Selection and Hiring of Quality Police Officers", Office of Criminal Justice Services, accessed on: http://www.ocjs. ohio.gov/Hiring_Quality_Officers.pdf

8. Fulero, S. M. and Wrightsman L. S. (2009), Forensic psychology (3rd ed.) Belmont, CA: Wadsworth, Cengage Learning.

9. Greene, E. and Heilburn, K. (2011), Wrightsman's Psychology and the Legal System (7th ed.). Belmont, CA: Wadsworth, Cengage Learning.

10. Hadžikadunić, A. and Turković, S. (2013), "Selekcija ljudskih resursa za potrebe policije primjenom bazično motoričkih testova", conference paper presented at Third International Conference "Sportske nauke i zdravlje", Panevropski Univerzitet 15.03.2013, Banjaluka.

11. Kastrelar V. E. and Gaines L. K. (2011), Community Policing: A Contemporary Perspective. Waltham, MA: Elsevier.

12. Kulić Ž. (2005), Upravljanje ljudskim potencijalima, Beograd: Radnička štampa.

13. Lee, T. L. (2007), "Psychological Standards", in: Greene, J. R., The Encyclopedia of Police Science (3rd ed.), New York: Routledge.

14. Malacko, J., Rađo, I. (2004), Nove tehnologije u sportu, Sarajevo: Fakultet sporta i tjelesnog odgoja.

15. Milanović, D. (1997), "Osnove teorija treninga" in: Priručnik za sportske trenere, Zagreb: Fakultet fizičke kulture. 
16. Ono, M. et al. (2011), "Cognitive Ability, Emotional Intelligence, and the Big Five Personality Dimensions as Predictors of Criminal Investigator Performance", Criminal Justice and Behavior, 38 (5).

17. Orlić R. (2005), Kadrovski menadžment, Beograd: Zoran Damjanović i sinovi.

18. Stanković, M. (2007), Menadžment ljudskih resursa u procesu transformacije, Beograd: VIPOS.

19. Šopar, J. (2004). Specifična i situacijska kondicijska priprema specijalnih postrojbi vojske i policije. (Graduate thesis). Zagreb: Kineziološki fakultet Sveučilišta u Zagrebu.

20. Toldson, I. A. (2006), Profiling Police: Evaluating the Predictive and Structural Validity of an Actuarial Method for Screening Civil Liabilities among Police Officer Candidates, National Criminal Justice Reference Service, accessed on https:// www.ncjrs.gov/pdffiles1/nij/grants/214121.pdf.

21. Zaciorski (1975), Fizička svojstva sportiste, Beograd: Savez za fizičku kulturu Jugoslavije.

22. Wright, A. J. (2011). Conducting Psychological Assessment: A Guide for Practitioners. Hoboken, NJ: John Wiley \& Sons. 